\title{
KEJADIAN MUNTAH PADA PENDERITA KANKER YANG MENJALANI PENGOBATAN KEMOTERAPI DI RSUP PROF. DR. R. D. KANDOU MANADO
}

\author{
${ }^{1}$ Bambang E. P. Hariyanto \\ ${ }^{2}$ Max F. J. Mantik \\ ${ }^{2}$ Audrey Wahani
}

\author{
${ }^{1}$ Kandidat Skripsi Fakultas Kedokteran Universitas Sam Ratulangi Manado \\ ${ }^{2}$ Bagian Ilmu Kesehatan Anak Fakultas Kedokteran Universitas Sam Ratulangi Manado \\ Email:db6378dk@gmail.com
}

\begin{abstract}
Chemotherapy-induced nausea and vomiting (CINV) are the most frequent and troublesome side effects in cancer patients. Cancer patients who are undergoing chemotherapy usually put nausea and vomiting in a list of side effects of chemotherapy that they are most worried about. Lack control of vomiting can disturb functional activities and quality of life of patients, increase the use of health service resources, and reduce the adherence to treatment. This was a descriptive study with a cross-sectional approach. This study used medical records of chemotherapy patients in Pediatrics Section of Prof. Dr. R. D. Kandou Hospital Manado in 2011 and 2012, particularly of those with ALL. There were 51 patients with ALL undergoing chemotherapy, and vomiting occured in 24 patients (47.1\%). The occurence of vomiting was more frequent among females (51.6\%), mostly during the induction and consolidation phases. Conclusion: In this study, vomiting occured most frequently among females, aged 6-10 years, during the consolidation phase of chemotherapy, especially with administration of HD-Mtx iv $1000 \mathrm{mg} / \mathrm{m}^{2}$.
\end{abstract}

Keywords: cancer patients, chemotherapy, vomiting effect

\begin{abstract}
Abstrak: Mual dan muntah akibat kemoterapi (CINV) merupakan efek samping yang sering terjadi dan memberikan banyak kesulitan pada pasien kanker. Pasien kanker yang menjalani kemoterapi biasanya menempatkan mual dan muntah pada daftar efek samping kemoterapi yang paling diresahkan. Kurangnya kontrol muntah dapat mengganggu aktivitas fungsional dan kualitas hidup pasien, meningkatkan penggunaan sumber daya pelayanan kesehatan, dan mengurangi kepatuhan terhadap pengobatan. Penelitian ini menggunakan metode deskriptif dengan pendekatan potong lintang. Penelitian ini menggunakan rekam medik dari efek muntah untuk kemoterapi pasien di Bagian Pediatri BLU RSUP Prof. Dr. R. D. Kandou Manado tahun 2011 dan 2012 terutama pada pasien dengan ALL. Selama periode tersebut terdapat 51 pasien yang menjalani kemoterapi ALL. Efek samping muntah dialami oleh 24 pasien (47,1\%). Kejadian ini tampaknya lebih menonjol pada wanita (51,6\%). Muntah kebanyakan terjadi selama fase induksi dan konsolidasi. Simpulan: Kejadian muntah terjadi lebih sering pada anak perempuan, usia 6-10 tahun, cenderung terjadi selama fase konsolidasi kemoterapi, dan terutama pada pemberian HDMtx iv: $1000 \mathrm{mg} / \mathrm{m}^{2}$.
\end{abstract}

Kata kunci: pasien kanker, kemoterapi, efek muntah

Penanganan kanker merupakan hal yang sangat menantang bagi pasien untuk menjalaninya. Penanganan kanker dan efek samping yang, dirasakan pasien lebih buruk dari kanker itu sendiri. Chemotherapy- induced nausea and vomiting (CINV) adalah dua dari banyak efek samping yang sering terjadi dan sangat menyusahkan bagi pasien kanker. Banyak pasien kanker yang akhirnya menunda penanganan kemoterapi 
atau menolak seluruhnya penanganan oleh rasa kuatir dengan CINV. ${ }^{1,2}$

Walaupun perkembangan telah dicapai dalam penanganan kanker, chemotherapyinduced vomiting (CIV) akut, chemotherapy-induced nausea (CIN), anticipatory nausea and vomiting (ANV), dan delayed nausea and vomiting (DNV) masih menjadi masalah substansial pagi pasien kanker. Anticipatory nausea dilaporkan sebesar $30 \%$ dari pasien yang mengalami nausea selama siklus penanganan kemoterapi awal. Anticipatory vomiting dilaporkan pada $20 \%$ pasien yang mengalami muntah selama sikus penanganan kemoterapi dini. Anticipatory, akut, dan CINV lambat, membuat kepatuhan paisen terhadap kemoterapi lebih rendah, melemahkan fungsi tubuh, meningkatkan kecemasan dan depresi, dan membatasi kualitas hidup diantara pasien. ${ }^{1}$

Pasien yang memulai terapi kanker biasanya memasukkan mual dan muntah dalam daftar efek samping kemoterapi yang merupakan salah satu ketakutan terbesar mereka. Dengan kurangnya kontrol terhadap emesis mengganggu aktifitas fungsional dan kualitas hidup pasien, meningkatkan penggunana sumber daya layanan kesehatan, dan bisa menurunkan kepatuhan terhadap penanganan. Wawasan baru kedalam patofisiologi dari mual muntah yang diinduksi oleh kemoterapi, suatu pemahanan yang lebih baik dari faktor resiko dari efek ini serta ketersediaan obat antimuntah baru, semuanya memberi kontribusi terhadap perbaikan substansial dalam kontrol muntah. ${ }^{1,3}$

Kemungkinan bahwa mual dan muntah akan berkembang sesudah penanganan kemoterapi tergantung pada berbagai faktor. Dua dari faktor-faktor ini adalah jenis kelamin dan umur, dengan pasien wanita dan umur lebih muda beresiko lebih besar. Selain itu, pasien yang dugaan yang tinggi akan mengalami mual berat sebelum penanganan, lebih mungkin mengalami mual sesudah kemoterapi. ${ }^{1,3}$

\section{METODE PENELITIAN}

Penelitian ini bersifat deskriptif dengan pendekatan potong lintang untuk mengetahui ada atau tidaknya muntah akibat kemoterapi pada anak-anak penderita kanker serta hubungan antara kemoterapi dengan kejadian muntah pada anak-anak penderita kanker. Yang akan diteliti ialah penderita kanker ALL yang menjalani kemoterapi di Bagian Pediatri BLU RSUP Dr. R. D. Kandou Manado periode 2011-2012.

\section{HASIL PENELITIAN DAN BAHASAN}

Penelitian tentang hubungan obat kemoterapi dengan kejadian muntah pada pasien yang menjalani kemoterapi, dilakukan di bagian Pediatri RSU Prof. R. D. Kandou periode 2012-2013. Penelitian ini dipersempit pada efek muntah penderita ALL yang ditangani dengan kemoterapi. Terdapat 51 kasus ALL yang ditangani selama periode tersebut.

Tabel 1. Karakteristik pasien ALL berdasarkan usia

\begin{tabular}{ccc}
\hline Usia & $\mathrm{n}$ & $\%$ \\
\hline $1-5$ & 17 & 33,4 \\
$6-10$ & 27 & 58,8 \\
$11-15$ & 4 & 7,8 \\
\hline
\end{tabular}

Tabel 2. Karakteristik muntah pada pasien berdasarkan jenis kelamin

\begin{tabular}{cccc}
\hline \multirow{2}{*}{$\begin{array}{c}\text { Jenis } \\
\text { kelamin }\end{array}$} & \multicolumn{2}{c}{ Muntah } & \\
\cline { 2 - 3 } & Tanpa & Dengan & Total \\
\cline { 2 - 3 } & $\mathrm{n}(\%)$ & $\mathrm{n}(\%)$ & \\
\hline Laki-laki & $12(60)$ & $8(40)$ & 20 \\
Perempuan & $15(48,4)$ & $16(51,6)$ & 31 \\
\hline
\end{tabular}


Jurnal e-Clinic (eCl), Volume 3, Nomor 3, September-Desember 2015

Tabel 3. Gambaran distribusi muntah terhadap jenis kelamin pada fase kemoterapi

\begin{tabular}{cccc}
\hline & \multicolumn{3}{c}{ Fase kemoterapi } \\
\cline { 2 - 4 } Jenis Kelamin & Fase induksi & Fase Konsolidasi & Fase Maintenance \\
& Jumlah & Jumlah & Jumlah \\
& $\mathrm{n}(\%)$ & $\mathrm{n}(\%)$ & $\mathrm{n}(\%)$ \\
\hline Laki-laki & 0 & $4(7,8)$ & $4(7,8)$ \\
Perempuan & $5(9,8)$ & $9(17,6)$ & $2(3,8)$ \\
\hline
\end{tabular}

Tabel 4. Gambaran distribusi muntah terhadap usia pada fase kemoterapi

\begin{tabular}{|c|c|c|c|}
\hline \multirow[b]{2}{*}{$\begin{array}{c}\text { Usia } \\
\text { (tahun) }\end{array}$} & \multicolumn{3}{|c|}{ Fase kemoterapi } \\
\hline & $\begin{array}{l}\text { Fase induksi } \\
\text { Jumlah } \\
\text { n (\%) }\end{array}$ & $\begin{array}{c}\text { Fase Konsolidasi } \\
\text { Jumlah } \\
\text { n (\%) }\end{array}$ & $\begin{array}{c}\text { Fase Maintenance } \\
\text { Jumlah } \\
\text { n (\%) }\end{array}$ \\
\hline $1-5$ & $2(3,9)$ & $5(9,8)$ & $1 \quad(1,9)$ \\
\hline $6-10$ & $3(5,9)$ & $8(15,7)$ & $5 \quad(9,8)$ \\
\hline $11-15$ & 0 & 0 & 0 \\
\hline
\end{tabular}

Meskipun terjadi perkembangan pada 20 tahun terakhir, mual dan muntah masih menjadi efek samping yang cukup signifikan pada terapi kanker. Mual dan muntah diakui baik di banyak situasi klinis yang beragam, menunjukkan bahwa tidak ada mekanisme tunggal yang mungkin berperan. Penggunaan obat sitotoksik dalam pengobatan berbagai penyakit berbahaya dapat menghasilkan toksisitas gastrointestinal yang parah. Mekanisme yang tepat dari kemoterapi menginduksi mual dan muntah masih kurang dipahami, namun apresiasi dari proses muntah tetap penting untuk pendekatan rasional terhadap terapi anti-muntah. ${ }^{5,6}$

Faktor resiko CINV termasuk jenis kelamin pasien dimana dari beberapa penelitian menunjukkan bahwa perempuan lebih rentan mengalami mual muntah selama kemoterapi dibandingkan lakilaki; ${ }^{4,7}$ umur lebih muda lebih sering mengalami muntah dibandingkan umur lebih tua ( $>3$ tahun), riwayat CINV sebelumnya, potensi emetogenik dari obat, dan jadwal pemberian kemoterapi. ${ }^{6,8}$

Dengan melihat pada fase dimana terjadi muntah, pada penelitian ini paling banyak pada fase induksi dan konsolidasi. Pasien perlu diproteksi dengan dosis antimetik sebelum memulai kemoterapi baik pada fase induksi, konsolidasi ataupun maintenance. Perlu dibuat panduan regimen pengobatan yang dirancang untuk mengurangi episode mual dan muntah akut akibat kemoterapi. Panduan umum menyebutkan bahwa 60 menit sebelum terapi untuk oral dan 30 menit sebelum terapi untuk anti emetic intravena. Formulasi oral ataupun intravena memiliki efikasi yang ekuivalen bila dosis didasarkan pada kemampuan bioavailabilitasnya. Rute oral harus digunakan lebih dulu dengan intravena sebagai cadangan bagi pasien yang tidak dapat mentoleransi dosis oral karena muntah persiten, mukositik berat, obstruksi mekanik, dll. ${ }^{9,10}$

\section{SIMPULAN}

Populasi sampel paling banyak berjenis kelamin perempuan. Kejadian muntah pada penderita ALL lebih banyak pada anak perempuan dibandingkan anak laki-laki. Usia 6-10 tahun lebih banyak mengalami kejadian muntah. Kejadian muntah paling sering terjadi pada fase konsolidasi dari kemoterapi. Obat yang digunakan pada fase konsolidasi adalah HD-Mtx i.v $1000 \mathrm{mg} / \mathrm{m}^{2}$

\section{SARAN}

Perlunya kelengkapan data pasiendengan kemoterapi yang mengalami kejadian muntah sebagai bahan acuan 
untuk penelitian berikutnya. Perlunya edukasi kepada orang tua atau keluarga pasien tentang efek samping obat kemoterapi yang digunakan untuk pengobatan kanker

\section{DAFTAR PUSTAKA}

1. Mustian KM, Devine K, Ryan JL, Janelsins MC, Sprod LK, Peppone $\mathbf{L J}$, et al. Treatment of nausea and vomiting during chemotherapy. Supportive oncology. 2011. p. 91-7.

2. American Cancer Society. Nausea and vomiting. 2013 [cited 2013 Nov 16]. Available from: http://www.cancer.org/treatment/tr eatmentsandsideeffects/physicalsi deeffects/nauseaandvomiting/naus ea-and-vomiting-landing

3. Hesketh PJ. Chemotherapy-induced nausea and vomiting. Drug therapy. N Engl J Med 2008;358:2482-94.

4. Kris MG, Hesketh PJ, Somerfield MR, Feyer P, Clark Snow R, Koeller JM, et al. American Society of Clinical Oncology guideline for antiemetics in oncology: update 2006. J Clin Oncol. 2006;24:2932-47.
5. Dewan P, Singhal S, Harit D. Management of chemotherapy-induced nausea and vomiting. Indian Pediatrics. 2010;47:149-54.

6. McNeil C, Howle E. Nausea and vomiting. University of Michigan Pediatric Heme/Onc Program Clinical Practice Guideline, 2012.

7. Lohr L. Chemotherapy-induced nausea and vomiting. Cancer J 2008;4:85-93.

8. Schwartberg LS. Chemotherapy-induced nausea and vomiting: which antiemetic for which therapy? Oncology. 2007;21: 946-53.

9. Sarcev T, Secen N, Zaric B, Milovancev A. Aprepitant- where do we stand in the control of chemotherapy-induced nausea and vomiting? J BUON 2008; 13:333-9.

10.Yeo W, Mo FK, Suen JJ, Ho WM, Chan SL, Lau W, et al. A randomized study of aprepitant, ondansetron and dexamethasone for chemotherapy induced nausea and vomiting in Chinese breast cancer patients receiving moderately emetogenic chemotherapy. Breast Cancer Res Treat. 2008;113:529-35. 